\title{
KEPASTIAN HUKUM INVESTASI MENURUT UNDANG UNDANG NOMOR 25 TAHUN 2007 TENTANG PENANAMAN MODAL DAN PERATURAN BADAN KOORDINASI PENANAMAN MODAL REPUBLIK INDONESIA NOMOR 5 TAHUN 2013 TENTANG PEDOMAN DAN TATA CARA PERIZINAN DAN NON PERIZINAN PENANAMAN MODAL ${ }^{1}$
}

(Studi Kasus PT. Tunas Mandiri Lumbis)

\author{
Oleh: Susanto \\ Dosen Universitas Pamulang \\ Email: Susantogss@yahoo.com
}

\begin{abstract}
Abstrak
Kepastian hukum dapat diwujudkan melalui penormaan yang baik dan jelas dalam suatu undang-undang dan akan jelas pula penerapannya. Kepastian hukum juga diperlukan dalam invetasi. Undang-Undang No. 25 tahun 2007 tentang Penanaman Modal pada tanggal 26 April 2007 Undang-undang ini telah disahkan untuk menggantikan Undang-undang No. 1 tahun 1967 tentang Penanaman Modal Asing dan Undang-undang No. 6 tahun 1968 tentang Penanaman Modal Dalam Negeri. Guna mengimplementasikan tugasnya sebagaimana disebutkan dalam UU Penanaman Modal, pada tanggal 12 April 2013 BKPM menerbitkan Peraturan Badan Koordinasi Penananaman Modal Republik Indonesia Nomor 5 Tahun 2013 Tentang Pedoman Dan Tata Cara Perizinan Dan Non Perizinan Penanaman Modal (Perka BKPM No.5 Tahun 2013) yang menggantikan Peraturan Kepala BKPM Nomor 12 Tahun 2009. Dalam Perka BKPM No.5 Tahun 2013 adalah sebagai panduan dalam layanan penanaman modal terkait prosedur pengajuan dan persyaratan permohonan perizinan dan nonperizinan penanaman modal yang ditujukan kepada pejabat di instansi penyelenggara Pelayanan Terpadu Satu Pintu (PTSP), para pelaku usaha serta masyarakat umum lainnya. Salah satu pemegang saham PT. Tunas Mandiri Lumbis mempermasalahkan penerbitan Ijin Prinsip Perubahan Penananaman Modal Asing Nomor 1723/1/IP-PB/PMA/2013, Nomor Perusahaan 24017, tertanggal 02 Desember 2013 di Pengadilan Tata Usaha Negara Jakarta. Ternyata dalam menerbitkan Ijin Prinsip Perubahan Penanaman Modal Asing harus memnuhi prosedur berdasarkan Undang-Undang Nomor 25 Tahun 2007 Tentang Penanaman Modal Pasal 25 ayat 4, Peraturan Kepala Badan Koordinasi Penanaman Modal Republik Indonesia Nomor 12 Tahun 2013 tentang perubahan atasa Peraturan Kepala Badan Koordinasi Penanaman Modal Nomor 5 Tahun 2013 tentang Pedoman dan tata cara perizinan dan non perizinan Penanaman Modal khususnya : Pasal 103 ayat (2), Pasal 103 ayat (3), Pasal 103 ayat (5) : Pasal 103 ayat (5) b : Pasal 103 ayat (6), Pasal 103 ayat (6) a. Tidak adanya kepastian hukum dalam Ijin Prinsip Perubahan Penananaman Modal Asing Nomor 1723/1/IP-PB/PMA/2013, Nomor Perusahaan 24017, tertanggal 02 Desember 2013 sebagaimana Putusan Pengadilan Tata Usaha Negara Jakarta Nomor : 43/G/2014/PTUN-JKT, tanggal 17 Juli 2014 karena telah melanggar prosedur yang ditentukan oleh Undang-Undang Nomor 25 Tahun 2007 Tentang Penanaman Modal
\end{abstract}

\footnotetext{
${ }^{1}$ Naskah diterima tanggal 3 Februari 2016, direvisi: 15 Maret 2016, disetujui untuk terbit 22 April 2016 dalam Volume 3 No.1 Juli 2016
} 
Pasal 25 ayat 4, Peraturan Pemerintah Nomor 38 Tahun 2007 tentang Pembagian Urusan Pemerintahan antara Pemerintah, Pemerintahan Daerah Provinsi dan Pemerintah Daerah Kabupaten/Kota, dan Peraturan Kepala Badan Koordinasi Penanaman Modal Republik Indonesia Nomor 12 Tahun 2013 tentang perubahan atas Peraturan Kepala Badan Koordinasi Penanaman Modal Nomor 5 Tahun 2013 tentang Pedoman dan tata cara perizinan dan non perizinan Penanaman Modal.

Kata Kunci : Kepastian Hukum, Investasi, Penanaman Modal

\begin{abstract}
Legal certainty can be realized through penormaan good and clear in a law and its application will also clear. Legal certainty is also required in invetasi. Law No. 25 of 2007 on Investment on April 26, 2007 This Act was passed to replace Law No. 1 of 1967 concerning Foreign Investment and Law No. 6 of 1968 concerning Domestic Investment. In order to implement its duties as stipulated in the Investment Law, on 12 April 2013 BKPM issued Regulation Penananaman Capital Coordinating Board Republic of Indonesia Number 5 Year 2013 on Guidelines and Procedures for Licensing and Non Licensing Investment (Perka BKPM No.5 of 2013) which replaces BKPM Chief Regulation No. 12 of 2009. in Perka BKPM 5 Year 2013 is to guide the investment services related to the application procedure and the licensing application requirements and capital investment nonperizinan addressed to officials in the agency organizer One Stop services (OSS), the businesses and the general public. One of the shareholders of PT. Mandiri Tunas Lumbis concerned Permit issuance principle Penananaman Change Foreign Investment Number 1723/1 / IP-PB / PMA / 2013, the Company No. 24017, dated December 2, 2013 at the Jakarta State Administrative Court. It turned out that in issuing the permit Principle Changes in Foreign Investment must comply with the procedures under Act No. 25 of 2007 on Investment Article 25, paragraph 4, Regulation of the Investment Coordinating Board of the Republic of Indonesia Number 12 Year 2013 regarding changes Atasa Regulation of the Investment Coordinating Board Number 5 Year 2013 on Guidelines and procedures for licensing and non-licensing Investment in particular: Article 103 paragraph (2), Article 103 paragraph (3), Article 103 paragraph (5): Article 103 paragraph (5) b: Article 103 paragraph (6), Article 103 paragraph (6) a. The absence of legal certainty in Permit Principle Changes Penananaman Foreign Investment Number 1723/1 / IP-PB / PMA / 2013, the Company Number 24017, dated December 2, 2013 as Court decision Jakarta State Administrative Number: 43 / G / 2014 / PTUN-JKT , dated July 17, 2014 for having violated the procedure established by Act No. 25 of 2007 on Investment Article 25, paragraph 4, of Government Regulation No. 38 of 2007 on the division of Government Affairs between the Government, Provincial Government and District Government / City, and Regulation of the Investment Coordinating Board of the Republic of Indonesia Number 12 Year 2013 concerning amendments to the Regulation of the Head of the Investment Coordinating Board No. 5 of 2013 on Guidelines and procedures for licensing and non-licensing of Investment.
\end{abstract}

KEYWORDS: Rule of Law, Investing, Investment 


\section{A. Pendahuluan}

Kepastian hukum dapat diwujudkan melalui penormaan yang baik dan jelas dalam suatu undang-undang dan akan jelas pula penerapannya. Kepastian hukum juga diperlukan dalam invetasi. Undang-Undang No. 25 tahun 2007 tentang Penanaman Modal pada tanggal 26 April 2007 Undang-undang ini telah disahkan untuk menggantikan Undang-undang No. 1 tahun 1967 tentang Penanaman Modal Asing dan Undang-undang No. 6 tahun 1968 tentang Penanaman Modal Dalam Negeri. Guna mengimplementasikan tugasnya sebagaimana disebutkan dalam UU Penanaman Modal, pada tanggal 12 April 2013 BKPM menerbitkan Peraturan Badan Koordinasi Penananaman Modal Republik Indonesia Nomor 5 Tahun 2013 Tentang Pedoman Dan Tata Cara Perizinan Dan Non Perizinan Penanaman Modal (Perka BKPM No.5 Tahun 2013) yang menggantikan Peraturan Kepala BKPM Nomor 12 Tahun 2009. Dalam Perka BKPM No.5 Tahun 2013 adalah sebagai panduan dalam layanan penanaman modal terkait prosedur pengajuan dan persyaratan permohonan perizinan dan nonperizinan penanaman modal yang ditujukan kepada pejabat di instansi penyelenggara Pelayanan Terpadu Satu Pintu (PTSP), para pelaku usaha serta masyarakat umum lainnya. Salah satu pemegang saham PT. Tunas Mandiri Lumbis mempermasalahkan penerbitan Ijin Prinsip Perubahan Penananaman Modal Asing Nomor 1723/1/IP-PB/PMA/2013, Nomor Perusahaan 24017, tertanggal 02 Desember 2013 di Pengadilan Tata Usaha Negara Jakarta. Ternyata dalam menerbitkan Ijin Prinsip Perubahan Penanaman Modal Asing harus memnuhi prosedur berdasarkan Undang-Undang Nomor 25 Tahun 2007 Tentang Penanaman Modal Pasal 25 ayat 4, Peraturan Kepala Badan Koordinasi Penanaman Modal Republik Indonesia Nomor 12 Tahun 2013 tentang perubahan atasa Peraturan Kepala Badan Koordinasi Penanaman Modal Nomor 5 Tahun 2013 tentang Pedoman dan tata cara perizinan dan non perizinan Penanaman Modal khususnya : Pasal 103 ayat (2), Pasal 103 ayat (3), Pasal 103 ayat (5) : Pasal 103 ayat (5) b : Pasal 103 ayat (6) , Pasal 103 ayat (6) a. Tidak adanya kepastian hukum dalam Ijin Prinsip Perubahan Penananaman Modal Asing Nomor 1723/1/IP-PB/PMA/2013, Nomor Perusahaan 24017, tertanggal 02 Desember 2013 sebagaimana Putusan Pengadilan Tata Usaha Negara Jakarta Nomor : 43/G/2014/PTUN-JKT, tanggal 17 Juli 2014 karena telah melanggar prosedur yang 
ditentukan oleh Undang-Undang Nomor 25 Tahun 2007 Tentang Penanaman Modal Pasal 25 ayat 4, Peraturan Pemerintah Nomor 38 Tahun 2007 tentang Pembagian Urusan Pemerintahan antara Pemerintah, Pemerintahan Daerah Provinsi dan Pemerintah Daerah Kabupaten/Kota, dan Peraturan Kepala Badan Koordinasi Penanaman Modal Republik Indonesia Nomor 12 Tahun 2013 tentang perubahan atas Peraturan Kepala Badan Koordinasi Penanaman Modal Nomor 5 Tahun 2013 tentang Pedoman dan tata cara perizinan dan non perizinan Penanaman Modal.

\section{B. Rumusan Masalah}

Berdasarkan uraian diatas maka dapat diambil suatu rumusan masalah yaitu :

1. Bagaimanakah prosedur penerbitan Ijin Prinsip Perubahan Penananaman Modal Asing berdasarkan Undang-Undang Nomor 25 Tahun 2007 Tentang Penanaman Modal ?

2. Bagaimana kepastian hukum izin investasi sesuai dengan prinsip Penanaman Modal Asing dikaitkan dengan Putusan Pengadilan Tata Usaha Negara Jakarta Nomor : 43/G/2014/PTUN-JKT, tanggal 17 Juli 2014 ?

\section{Metode Penelitian}

Metode pendekatan yang dipakai adalah pendekatan yuridis normatif yaitu pendekatan yang menggunakan legis positivis, yang menyatakan bahwa hukum identik dengan norma-norma tertulis yang dibuat dan diundangkan oleh lembaga atau pejabat yang berwenang. Selain itu konsepsi ini memandang hukum sebagai suatu sistem normatif yang bersifat otonom, tertutup dan terlepas dari kehidupan masyarakat. ${ }^{2}$ Metode pendekatan yuridis normatif digunakan dengan tujuan untuk menganalisis kepastian hukum Peraturan Badan Koordinasi Penananaman Modal Republik Indonesia Nomor 5 Tahun 2013 Tentang Pedoman Dan Tata Cara Perizinan Dan Non Perizinan Penanaman Modal (Perka BKPM No.5 Tahun 2013).

Dalam usaha memperoleh data yang diperlukan untuk menyusun penulisan hukum, maka akan dipergunakan spesifikasi penelitian Preskripsi. Spesifikasi penelitian ini adalah Preskripsi, yaitu suatu penelitian yang menjelaskan keadaan

\footnotetext{
2 Peter Mahmud Marzuki, Penelitian Hukum, Kencana Prenada Media Group, Jakarta, 2005, hal.37.
} 
obyek yang akan diteliti melalui kaca mata disiplin hukum, atau sering disebut oleh Peter Mahmud Marzuki sebagai yang seyogyanya. ${ }^{3}$ Dalam hal ini penelitian ditujukan untuk mendapatkan gambaran yang seyogyanya tentang kepastian hukum Peraturan Badan Koordinasi Penananaman Modal Republik Indonesia Nomor 5 Tahun 2013 Tentang Pedoman Dan Tata Cara Perizinan Dan Non Perizinan Penanaman Modal (Perka BKPM No.5 Tahun 2013).

\section{Tujuan Penelitian}

Penelitian ini dilakukan dengan tujuan untuk:

1. Memahami prosedur penerbitan Ijin Prinsip Perubahan Penananaman Modal Asing berdasarkan Undang-Undang Nomor 25 Tahun 2007 Tentang Penanaman Modal.

2. Mengetahui kepastian hukum izin investasi sesuai dengan prinsip Penanaman Modal Asing.

\section{E. Pembahasan}

\section{Kebijakan Umum Penanaman Modal}

Indonesia sebagai suatu Negara yang mendambakan suatu masyarakat yang adil dan makmur harus selalu melakukan pembangunan dalam berbagai bidang, di antaranya pembangunan dalam bidang ekonomi. Pembangunan ekonomi identik dengan pembangunan sektor-sektor ekonomi yang terdapat di Negara itu sendiri, seperti: sektor pertanian, perikanan, peternakan, pertambangan, industri, perdagangan, jasa-jasa, dan selainnya. ${ }^{4}$ Konsekuensi pelaksanaan pembangunan ekonomi tersebut diperlukan adanya modal atau investasi yang besar dalam melakukan pembangunan. Dari investasi yang menunjang pembangunan ekonomi dimaksud, kemudian dikenal adanya kegiatan penanaman modal (investasi) di Indonesia yang dimulai pada Tahun 1967, tepatnya sejak dikeluarkannya UU No. 1 Tahun 1967 tentang Penanaman Modal Asing, dan UU No. 6 Tahun 1968 tentang Penanaman Modal Dalam Negeri. ${ }^{5}$

\footnotetext{
${ }^{3}$ Ibid., hal 91 .

${ }^{4}$ Aminuddin Ilmar, Hukum Penanaman Modal di Indonesia, Jakarta, Kencana, Jakarta, 2004, hal.

${ }^{5}$ Salim HS dan Budi Sutrisno, Hukum Investasi di Indonesia, Jakarta, Sinar Grafika, 2010, hal. 3.
} 1. 
Kegiatan Penanaman Modal atau investasi (invest) dapat diartikan sebagai suatu kegiatan yang dilakukan baik oleh orang pribadi (natural person) maupun badan hukum (juridical person) dalam upaya untuk meningkatkan dan/atau mempertahankan nilai modalnya, baik yang berbentuk uang tunai (cash money), peralatan (equipment). Asset tidak bergerak, hak atas kekayaan intelektual (HaKI), maupun keahlian. ${ }^{6}$ Hal dimaksud, disebutkan dalam Undang-Undang No. 25 Tahun 2007 tentang Penanaman Modal yang merupakan jawaban atas perkembangan kegiatan penanaman modal/ investasi dari Tahun 1967 sebagaimana yang telah diuraikan sebelumnya. Dalam Pasal 1 ayat (1) UU Penanaman Modal tersebut dinyatakan bahwa "Penanaman modal adalah segala bentuk kegiatan menanam modal, baik oleh penanam modal dalam negeri maupun penanam modal asing untuk melakukan usaha di wilayah negara Republik Indonesia". ${ }^{7}$

Pengaturan Penanaman Modal dalam UU No. 25 Tahun 2007 tentang Penanaman Modal, dan Peraturan Perundang-Undangan lainnya yang mengatur investor bagi warga Negara Indonesia dan bagi Negara lain (Penanaman Modal Asing) seperti, UU No 12 Tahun 1970 tentang Perubahan dan Tambahan Atas UU No 6 Tahun 1968 tentang Penanaman Modal Dalam Negeri, UU No. 11 Tahun 1970 tentang Perubahan dan Tambahan Atas UU No. 1 Tahun 1967 tentang Penanaman Modal Asing, PP No. 17 Tahun 1992 tentang Persyaratan Pemilikan Saham dalam Perusahaan Penanaman Modal Asing, dan juga beberapa Kepres dan Kepmen serta keputusan Kepala BKPM, dan selainnya. ${ }^{8}$

Ada beberapa dasar hukum dalam Penanaman Modal yang dikemukakan di atas serta beberapa ketentuan-ketentuan pokok yang menjadi acuan dalam melaksanakan kegiatannya, baik bidang usaha maupun beberapa aspek lainnya, seperti aspek kelembagaan, ketenagakerjaan, aspek perlindungan hukum dan selainnya. Disinilah terlihat sangat penting untuk memahami ketentuanketentuan pokok dalam bidang penanaman modal tersebut, agar semakin jelas

${ }^{6}$ Ana Rokhmatussa'diyah dan Suratman, Hukum Investasi dan Pasar Modal, Jakarta, Sinar Grafika, 2010, hal. 3.

${ }^{7}$ Undang-Undang No. 25 Tahun 2007 tentang Penanaman Modal.

${ }^{8}$ Salim HS dan Budi Sutrisno, Hukum Investasi di Indonesia, Jakarta, Sinar Grafika, 2010, hal. 17. 
dalam menjalankan aturan-aturan yang terkait, dan juga agar dapat melaksanakan investasi dengan baik. ${ }^{9}$

Wilayah negara republik Indonesia memiliki berbagai potensi yang sangat besar antara lain: Memiliki wilayah yang sangat subur dengan kekayaan alam yang berlimpah; Upah buruh yang relatif rendah; Pasar yang sangat besar; Lokasi yang strategis; Adanya upaya sungguh-sungguh pemerintah untuk mendorong iklim investasi yang sehat; Tidak adanya pembatasan arus devisa, tennasuk atas modal dan keuntungan, dan lain-lain. ${ }^{10}$

Namun di samping potensi yang besar dimaksud, Indonesia memiliki beberapa kelemahan yang menjadi kendala dalam menarik investasi, seperti: Kurangnya keterampilan tenaga kerja yang ada; Birokrasi yang terkadang berbelit sehingga dapat membengkakkan biaya awal operasi; Stabilitas keamanan yang agak kurang stabil sejak beberapa tahun terakhir (sejak 1997); Kebijakan yang seringkali berubah-ubah; Kurangnya kepastian hukum; Mekanisme penyelesaian sengketa yang kurang kredibel, sehingga kurang menguntungkan investor; Kurangnya tranparasi, dan lain-lain. ${ }^{11}$ Padahal sebelum krisis merebak (pra-1997), iklim penanaman modal di Indonesia dipandang cukup menarik bagi investor asing dan investor dalam negeri karena lingkungan politik yang relatif stabil, meskipun stabilitas yang didapat saat itu harus dibayar mahal. Sementara sekarang para investor tampaknya masih menahan diri untuk berinvestasi dan menunggu iklim politik Indonesia yang lebih favourable untuk memulai investasinya.

Dalam menghadapi kenyataan yang terjadi dimaksud, diperlukan kebijakan-kebijakan mengenai investasi, baik oleh pemerintah maupun rakyat, agar dapat memulihkan kembali kondisi perkonomian Indonesia yang sempat terpuruk sehingga dapat menciptakan lapangan pekerjaan yang baru, meningkatkan keterampilan tenaga kerja lokal, dan pada akhirnya mensejahterahkan rakyat.

${ }^{9}$ H. Zainuddin Ali, Aspek Hukum Penanaman Modal di Indonesia, Yayasan Masyarakat Indonesia Baru, 2014. hal 17.

10 Ana Rokhmatussa'diyah dan Suratman, Hukum Investasi dan Pasar Modal, Jakarta, Sinar Grafika, 2010, hal. 56.

${ }^{11}$ Ibid. 
Langkah-langkah yang sudah, sedang dan yang akan ditempuh dalam menciptakan iklim investasi yang favourable tersebut mencakup hal-hal sebagai berikut.

1. Menyederhanakan proses dan tata cara perizinan dan persetujuan dalam rangka penanaman modal;

2. Membuka secara lebih luas bidang-bidang yang semula tertutup atau dibatasi dengan penanaman modal asing;

3. Memberikan skema insentif, baik pajak maupun non-pajak;

4. Mengembangkan kawasan-kawasan untuk menanamkan modal dengan berbagai kemudahan yang ditawarkan;

5. Menyempurnakan berbagai produk hukum dengan menge-luarkan peraturan-perundang-undangan bam yang lebih menjamin iklim investasi yang sehat;

6. Menyempurnakan proses penegakan hukum dan penyelesaian sengketa yang efektif dan adil;

7. Menyempurnakan tugas, fungsi dan wewenang instasi terkait untuk dapat memberikan pelayanan yang lebih baik;

8. Membuka kemungkinan pemilikan saham asing yang lebih besar dan lainlain. $^{12}$

Langkah-langkah dimaksud, sebagian sudah dapat diwujudkan, sebagaimana terlihat dengan munculnya berbagai produk hukum yang lebih menjamin iklim investasi yang sehat, misalnya UU No. 4 Tahun 1998 tentang Penetapan Pemerintah Pengganti Undang-Undang No. 1 Tahun 1998 tentang Perubahan Atas Undang-Undang Kepailitan Menjadi Undang-Undang, UU No. 5 Tahun 1999 tentang Larangan Praktik monopoli dan Persaingan Usaha Tidak Sehat, UU No. 8 Tahun 1999 tentang Perlindungan Konsumen, UU No. 30 Tahun 1999 tentang Arbitrase dan Alternatif Penyelesaian Sengketa, Keppres Nomor 183 Tahun 1998 tentang Badan kordinasi Penanaman Modal, dan UU No. 25 Tahun 2007 tentang Penanaman Modal yang menjanjikan beragam insentif dan jaminan bagi para investor, ${ }^{13}$ serta Perundang-undangan lainnya

\footnotetext{
${ }^{12}$ Ibid. Hal 57-58.

${ }^{13}$ Ibid. Hal 58-59.
} 
yang terkait dengan kebijakan-kebijakan dalam melakukan investasi baik bagi Warga Negara Indonesia maupun bagi Warga Negara Asing yang melakukan investasi di Indonesia. ${ }^{14}$

\section{Badan Koordinasi Penanaman Modal Republik Indonesia}

Badan Koordinasi Penanaman Modal (bahasa Inggris: Investment Coordinating Board) adalah Lembaga Pemerintah Non Departemen Indonesia yang bertugas untuk merumuskan kebijakan pemerintah di bidang penanaman modal, baik dari dalam negeri maupun luar negeri. Badan ini didirikan sejak tahun 1973, menggantikan fungsi yang dijalankan oleh Panitia Teknis Penanaman Modal yang dibentuk sebelumnya pada tahun 1968.

Dengan ditetapkannya Undang-Undang tentang Penanaman Modal pada tahun 2007, BKPM menjadi sebuah lembaga Pemerintah yang menjadi koordinator kebijakan penanaman modal, baik koordinas antar instansi pemerintah, pemerintah dengan Bank Indonesia, serta pemerintah dengan pemerintah daerah maupun pemerintah daerah dengan pemerintah daerah. BKPM juga diamanatkan sebagai badan advokasi bagi para investor, misalnya menjamin tidak adanya ekonomi biaya tinggi. Sekarang ini BKPM dipimpin oleh Ir. Franky Sibarani yang dilantik pada 27 November 2014 oleh Presiden Joko Widodo. ${ }^{15}$

3. Susunan Kedudukan Badan Koordinasi Penanaman Modal Republik Indonesia

Sesuai dengan Peraturan Presiden Republik Indonesia Nomor 90 Tahun 2007 Tentang Badan Koordinasi Penanaman Modal, tanggal 3 September 2007 pada Bab I mengenai Kedudukan, Tugas, dan Fungsi menyebutkan sebagai berikut :

Pasal 1

${ }^{14}$ H. Zainuddin Ali, Aspek Hukum Penanaman Modal di Indonesia, Yayasan Masyarakat Indonesia Baru, 2014. hal 19.

${ }^{15}$ http://id.wikipedia.org/wiki/Badan_Koordinasi_Penanaman_Modal diakses tanggal 23 Januari 2015. 
(1) Badan Koordinasi Penanaman Modal, yang selanjutnya dalam Peraturan Presiden ini disebut BKPM, adalah Lembaga Pemerintah Non Departemen yang berada di bawah dan bertanggung jawab langsung kepada Presiden.

(2) BKPM dipimpin oleh seorang Kepala.

\section{Tugas dan Kewenangan Badan Koordinasi Penanaman Modal Republik} Indonesia

Sesuai dengan Peraturan Presiden Republik Indonesia Nomor 90 Tahun 2007 Tentang Badan Koordinasi Penanaman Modal, tanggal 3 September 2007 pada Bab I mengenai Kedudukan, Tugas, dan Fungsi menyebutkan sebagai berikut :

\section{Pasal 2}

BKPM mempunyai tugas melaksanakan koordinasi kebijakan dan pelayanan di bidang penanaman modal berdasarkan ketentuan peraturan perundangundangan.

Pasal 3

Dalam melaksanakan tugas sebagaimana dimaksud dalam Pasal 2, BKPM menyelenggarakan fungsi :

a. pengkajian dan pengusulan perencanaan penanaman modal nasional;

b. koordinasi pelaksanaan kebijakan nasional di bidang penanaman modal;

c. pengkajian dan pengusulan kebijakan pelayanan penanaman modal;

d. penetapan norma, standar, dan prosedur pelaksanaan kegiatan dan pelayanan penanaman modal;

e. pengembangan peluang dan potensi penanaman modal di daerah dengan memberdayakan badan usaha;

f. pembuatan peta penanaman modal di Indonesia;

g. koordinasi pelaksanaan promosi serta kerjasama penanaman modal;

h. pengembangan sektor usaha penanaman modal melalui pembinaan penanaman modal, antara lain meningkatkan kemitraan, meningkatkan daya saing, menciptakan persaingan usaha yang sehat, dan menyebarkan informasi yang seluas-luasnya dalam lingkup penyelenggaraan penanaman modal; 
i. pembinaan pelaksanaan penanaman modal, dan pemberian bantuan penyelesaian berbagai hambatan dan konsultasi permasalahan yang dihadapi penanam modal dalam menjalankan kegiatan penanaman modal;

j. $\quad$ koordinasi dan pelaksanaan pelayanan terpadu satu pintu;

k. koordinasi penanam modal dalam negeri yang menjalankan kegiatan penanaman modalnya di luar wilayah Indonesia;

1. pemberian pelayanan perizinan dan fasilitas penanaman modal;

m. pembinaan dan pelayanan administrasi umum di bidang perencanaan umum, ketatausahaan, organisasi dan tatalaksana, kepegawaian, pendidikan dan pelatihan, keuangan, hukum, kearsipan, pengolahan data dan informasi, perlengkapan dan rumah tangga; dan

n. pelaksanaan fungsi lain di bidang penanaman modal sesuai dengan ketentuan peraturan perundang-undangan.

\section{Kewenangan Badan Koordinasi Penanaman Modal Republik Indonesia} Menerbitkan Ijin Prinsip Perubahan Penananaman Modal Asing

Dalam ketentuan pasal 5 Peraturan Pemerintah Nomor 38 Tahun 2007 tentang Pembagian Urusan Pemerintahan antara Pemerintah, Pemerintah Daerah Provinsi dan Pemerintah Daerah Kabupaten / Kota disebutkan :

(1) Pemerintah mengatur dan mengurus urusan pemerintahan yang menjadi kewenangannya sebagaimana dimaksud dalam pasal 2 ayat (2). ;

(2) Khusus untuk urusan pemerintahan di bidang penanaman modal, penetapan kebijakan dilakukan sesuai peraturan perundang-undangan. ;

Selanjutnya dalam ketentuan Peraturan Kepala Koordinasi Penanaman Modal Republik Indonesia Nomor 12 Tahun 2013 tentang perubahan atas Peraturan Kepala Badan Koordinasi Penanaman Modal Nomor 5 Tahun 2013 tentang Pedoman dan Tata cara Perizinan dan non perizinan Penanaman Modal telah diatur bahwa :

a. Pasal 1 angka 6 : Perizinan adalah segala bentuk persetujuan untuk melakukan Penanaman MOdal yang dikeluarkan oleh Pemerintah, Pemerintah Daerah yang memiliki kewenangan sesuai dengan ketentuan peraturan perundang-undangan. ;

b. Pasal 1 angka 22 : Izin Prinsip Perubahan Penanaman Modal yang 
selanjutnya disebut izin Prinsip perubahan adalah izin prinsip yang wajib dimiliki perusahaan dalam rangka legalisasi perubahan rencana atau realisasi penanaman modal yang telah ditetapkan sebelumnya. ;

c. Pasal 1 angka 31 : Badan Koordinasi Penanaman Modal yang selanjutnya disebut BKPM adalah lembaga pemerintah non kementrian yang bertanggungjawab dibidang Penanaman Modal, yang dipimpin oleh seorang kepala yang berada dibawah dan bertanggungjawab langsung kepada Presiden.;

\section{Prosedur Penerbitan Ijin Prinsip Perubahan Penananaman Modal Asing}

Peraturan Kepala Badan Koordinasi Penanaman Modal Republik Indonesia Nomor 12 Tahun 2013 tentang perubahan atasa Peraturan Kepala Badan Koordinasi Penanaman Modal Nomor 5 Tahun 2013 tentang Pedoman dan tata cara perizinan dan non perizinan Penanaman Modal khususnya :

1) Pasal 103 ayat (2) mengatur : permohonan perizinan dan non perizinan penanaman modal yang diajukan setelah berstatus badan hukum indonesia, harus ditandatangani oleh direksi/pimpinan perusahaan. ;

2) Pasal 103 ayat (3) mengatur : penandatanganan permohonan sebagaimana dimaksud pada ayat (2) dapat dilakukan oleh karyawan perusahaan satu level dibawah jabatan direksi/pimpinan perusahaan dilengkapi dengan :

a. Surat dari direksi/pimpinan perusahaan yang menyatakan penjelasan tentang kondisi yang tidak memungkinkan bagi direksi atau pimpinan perusahaan mengetahui serta menyetujui permohonan yang disampaikan;

b. Surat perintah tugas dari direksi/pimpinan perusahaan;

c. Rekaman identitas diri direksi/pimpinan perusahaan dengan menunjukkan aslinya; dan

d. Bagi penerima kuasa dibuktikan dengan rekaman identitas diri dan surat pengangkatan terakhir sebagai karyawan dengan menunjukkan aslinya. ;

3) Pasal 103 ayat (5) : permohonan sebagaimana dimaksud pada ayat (1) dan ayat (2) diajukan ke PTSP BKPM, PDPPM/instansi penyelenggara PTSP KPBPB, PTSP KEK sesuai kewenangannya. ;

4) Pasal 103 ayat (5) b : pengajuan permohonan sebagaimana dimaksud pada ayat (2) dilakukan oleh direksi/pimpinan perusahaan atau dari salah satu 
dari pihak-pihak dibawah ini berdasarkan surat kuasa dari direksi/pimpinan perusahaan tanpa hak substitusi, yaitu oleh :
a. Karyawan Perusahaan ;
b. Advokat perseorangan ;
c. Advokat yang membentuk persekutuan perdata sebagai konsultan hukum;
d. Notaris;
e. Perwakilan Kamar Dagang dan Industri dari negara calon pemegang saham perusahaan; atau
f. Perusahaan Penanaman Modal Dalam Negeri dibidang usaha jasa konsultasi.

5) Pasal 103 ayat (6) : pengajuan permohonan yang dilakukan oleh pihak sebagaimana dimaksud pada ayat (5) a dan ayat (5) b huruf c, huruf d. Huruf e dan huruf $\mathrm{f}$ dapat ditugaskan kepada associate/karyawan kantor/perusahaan yang mempunyai kompetensi dan kemampuan untuk memberikan keterangan yang lengkap dan akurat serta bertanggungjawab atas seluruh informasi yang disampaikan. ;

6) Pasal 103 ayat (6) a : pejabat di PTSP BKPM, PDPPM / instansi penyelenggara PTSP di provinsi, PDKPM/instansi penyelenggara PTSP di kabupaten/kota, PTSP KPBPB, PTSP KEK sesuai kewenangannya, berhak menolak permohonan yang disampaikan oleh associate / karyawan kantor / perusahaan yang tidak mempunyai kompetensi dan kemampuan untuk memberikan keterangan yang lengkap dan akurat.;

7. Kepastian Hukum dan Keadilan dalam Ijin Prinsip Perubahan Penananaman Modal Asing Nomor 1723/1/IP-PB/PMA/2013, Nomor Perusahaan 24017, tertanggal 02 Desember 2013

Tugas dan wewenang BKPM sesuai dengan Peraturan Presiden Republik Indonesia Nomor 90 Tahun 2007 Tentang Badan Koordinasi Penanaman Modal, tanggal 3 September 2007 pada Bab I mengenai Kedudukan, Tugas, dan Fungsi menyebutkan sebagai berikut :

Pasal 2 
BKPM mempunyai tugas melaksanakan koordinasi kebijakan dan pelayanan di bidang penanaman modal berdasarkan ketentuan peraturan perundang-undangan.

BKPM dalam melaksanakan tugas dan kewenangannya memiliki UndangUndang Nomor 25 tahun 2007 tentang Penanaman Modal. Dengan ditetapkannya Undang-Undang Nomor 25 tahun 2007 tentang Penanaman Modal, BKPM menjadi sebuah lembaga Pemerintah yang menjadi koordinator kebijakan penanaman modal, baik koordinas antar instansi pemerintah, pemerintah dengan Bank Indonesia, serta pemerintah dengan pemerintah daerah maupun pemerintah daerah dengan pemerintah daerah. BKPM juga diamanatkan sebagai badan advokasi bagi para investor, misalnya menjamin tidak adanya ekonomi biaya tinggi.

Lembaga Pemerintah Nonkementerian disingkat (LPNK), dahulu bernama Lembaga Pemerintah Nondepartemen (LPND) adalah lembaga negaradi Indonesia yang dibentuk untuk melaksanakan tugas pemerintahan tertentu dari presiden. Kepala LPNK berada di bawah dan bertanggung jawab langsung kepada presiden melalui menteri atau pejabat setingkat menteri yang mengoordinasikan. ${ }^{16}$

Berdasarkan ketentuan pasal 5 Peraturan Pemerintah Nomor 38 Tahun 2007 tentang Pembagian Urusan Pemerintahan antara Pemerintah, Pemerintah Daerah Provinsi dan Pemerintah Daerah Kabupaten / Kota disebutkan :

(1) Pemerintah mengatur dan mengurus urusan pemerintahan yang menjadi kewenangannya sebagaimana dimaksud dalam pasal 2 ayat (2). ;

(2) Khusus untuk urusan pemerintahan di bidang penanaman modal, penetapan kebijakan dilakukan sesuai peraturan perundang-undangan. ;

Selanjutnya dalam ketentuan Peraturan Kepala Koordinasi Penanaman Modal Republik Indonesia Nomor 12 Tahun 2013 tentang perubahan atas Peraturan Kepala Badan Koordinasi Penanaman Modal Nomor 5 Tahun 2013 tentang Pedoman dan Tata cara Perizinan dan non perizinan Penanaman Modal telah diatur bahwa :

\footnotetext{
${ }^{16}$ Bab VI Pasal 25 Ayat 2 Undang-Undang Republik Indonesia Nomor 39 Tahun 2008 Tentang Kementrian Negara.
} 
a. Pasal 1 angka 6 : Perizinan adalah segala bentuk persetujuan untuk melakukan Penanaman Modal yang dikeluarkan oleh Pemerintah, Pemerintah Daerah yang memiliki kewenangan sesuai dengan ketentuan peraturan perundang-undangan. ;

b. Pasal 1 angka 22 : Izin Prinsip Perubahan Penanaman Modal yang selanjutnya disebut izin Prinsip perubahan adalah izin prinsip yang wajib dimiliki perusahaan dalam rangka legalisasi perubahan rencana atau realisasi penanaman modal yang telah ditetapkan sebelumnya. ;

c. Pasal 1 angka 31 : Badan Koordinasi Penanaman Modal yang selanjutnya disebut BKPM adalah lembaga pemerintah non kementrian yang bertanggungjawab dibidang Penanaman Modal, yang dipimpin oleh seorang kepala yang berada dibawah dan bertanggungjawab langsung kepada Presiden.;

Bahwa berdasarkan ketentuan tersebut ternyata terdapat kewenangan BKPM menerbitkan Ijin Prinsip Perubahan Penananaman Modal Asing Nomor 1723/1/IP-PB/PMA/2013, Nomor Perusahaan 24017, tertanggal 02 Desember 2013.

Peraturan BKPM Nomor : 5 Tahun 2013 Tentang Pedoman dan Tata Cara Perizinan dan Non Perizinan Penanaman Modal, merupakan salah satu wujud peraturan perundang-undangan yang sah dan legitimate berlaku di Negara Indonesia. Hal ini ditegaskan dalam Pasal 7 ayat (1) Undang-undang Nomor 12 Tahun 2011 tentang Pembentukan Peraturan Perundang-undangan, yang menegaskan bahwa, jenis dan hierarki Peraturan Perundang-undangan terdiri atas:

1. Undang-Undang Dasar Negara Republik Indonesia Tahun 1945;

2. Ketetapan Majelis Permusyawaratan Rakyat;

3. Undang-Undang/Peraturan Pemerintah Pengganti Undang-Undang;

4. Peraturan Pemerintah;

5. Peraturan Presiden;

6. Peraturan Daerah Provinsi; dan

7. Peraturan Daerah Kabupaten/Kota. 
Berdasarkan Undang-undang Nomor 12 Tahun 2011 tentang Pembentukan Peraturan Perundang-undangan, maka Peraturan BKPM Nomor : 5 Tahun 2013 Tentang Pedoman dan Tata Cara Perizinan dan Non Perizinan Penanaman Modal dapat dikatakan sebagai salah satu sumber hukum.

Kedudukan Peraturan BKPM Nomor : 5 Tahun 2013 Tentang Pedoman dan Tata Cara Perizinan dan Non Perizinan Penanaman Modal tidak bisa dipisahkan dengan kedudukan dan kewenangan BKPM dalam sistem ketatanegaraan Indonesia.

Untuk melihat kedudukan Peraturan BKPM Nomor : 5 Tahun 2013 Tentang Pedoman dan Tata Cara Perizinan dan Non Perizinan Penanaman Modal dalam sistem perundang-undangan Indonesia, baiknya kita memulai dari teori piramida hukum (stufentheorie) yang diperknalkan oleh Hans Kelsen. Teori tersebut memberikan kategorisasi atau pengelompokan terhadap beragam norma hukum dasar yang berlaku. Teori Hans Kelsen ini kemudian dikembangkan oleh Hans Nawiasky melalui teori yang disebut dengan "theorie von stufenufbau der rechtsordnung". Teori ini memberikan penjelasan susunan norma sebagai berikut :

1. Norma fundamental negara (Staatsfundamentalnorm);

2. Aturan dasar negara (staatsgrundgesetz);

3. Undang-undang formal (formell gesetz); dan

4. Peraturan pelaksanaan dan peraturan otonom (verordnung en autonome satzung). ${ }^{17}$

Berdasarkan teori Hans Nawiasky tersebut, A. Hamid S. Attamimi mencoba mengaplikasikannya kedalam struktur hierarki perundang-undangan yang berlaku di Indonesia. Berdasarkan teori Nawiasky tersebut, maka tata urutan perundangundangan di Indonesi adalah sebagai berikut :

1. Staatsfundamentalnorm : Pancasila (Pembukaan UUD 1945).

17 A. Hamid A. Attamimi, 1990. Peranan Keputusan Presiden Republik Indonesia dalam Penyelenggaraan Pemerintahan Negara; Suatu Studi Analisis Mengenai Keputusan Presiden yang Berfungsi Pengaturan dalam Kurun Waktu Pelita I-Pelita IV, Disertasi Ilmu Hukum Fakultas Pascasarjana Universitas Indonesia, Jakarta. Hal. 287. 
2. Staatsgrundgesetz : Batang Tubuh UUD 1945, Tap MPR, dan Konvensi Ketatanegaraan.

3. Formell gesetz : Undang-Undang.

4. Verordnung en Autonome Satzung : Secara hierarkis mulai dari Peraturan Pemerintah hingga Keputusan Bupati atau Walikota ${ }^{18}$.

Secara garis besar, Peraturan BKPM Nomor : 5 Tahun 2013 Tentang Pedoman dan Tata Cara Perizinan dan Non Perizinan Penanaman Modal dikategorikan sebagai Verordnung en Autonome Satzung.

Peraturan Pelaksanaan dan Peraturan Otonom ini merupakan peraturanperaturan yang terletak di bawah undang-undang yang berfungsi menyelenggarakan ketentuan-ketentuan dalam undang-undang. Peraturan Pelaksanaan bersumber dari kewenangan delegasi sedangkan Peraturan Otonom bersumber dari kewenangan atribusi. Atribusi kewenangan adalah pembentukan Peraturan Perundang-undangan (attributie van wetgevingsbevoegdheid) ialah pemberian kewenangan membentuk peraturan perundang-undangan yang diberikan oleh Undang-undang kepada suatu lembaga negara atau pemerintahan. Kewenangan tersebut melekat terus-menerus dan dapat dilaksanakan atas prakarsa sendiri setiap waktu diperlukan, sesuai dengan batas-batasyang diberikan. Delegasi Kewenangan dalam pembentukan Peraturan Perundangan-undangan (delegatie van wetgevingsbevoegdheid)ialah pelimpahan kewenangan membentuk peraturan perundang-undangan yang dilakukan oleh peraturan perundang-undangan yanglebih tinggi kepada peraturan perundang-undangan yang lebih rendah.

Sistem hierarki yang terdapat dalam Undang-udang Nomor 12 Tahun 2011 tentang Pembentukan Peraturan Perundang-undangan mendasarkan pada prinsip hierakhie peraturan perundang-undangan, maka Undang-udang ini menetapkan beberapa jenis peraturan perundang-undangan yang berbasiskan hierarkhie struktural yang menjadi prinsip utama dalam sistem norma Negara Kesatuan Republik Indonesia. Hierarkhie struktural menggambarkan hierarkhie susunan lembaga-lembaga negara/pemerintah yang berwenang dalam penyelenggaraan pemerintahan.Namun pada sisi lain, Undang-udang ini juga mengakui "hierakhie

\footnotetext{
${ }^{18}$ Ibid., hal. 359.
} 
fungsional" artinya berdasarkan kewenangan delegasi, suatu undang-undang dapat menentukan pengaturan lebih lanjut materi tertentu dengan peraturan perundangundangan yang tidak terdapat dalam hirarkhie struktural. Misalnya, delegasi langsung dari undang-undang untuk mengatur lebih lanjut dengan peraturan.

Berdasarkan uraian di atas penulis memiliki pendapat bahwa, Peraturan BKPM Nomor : 5 Tahun 2013 Tentang Pedoman dan Tata Cara Perizinan dan Non Perizinan Penanaman Modal dalam penelitian tersebut tidak memberikan kepastian hukum oleh karena itu perlu diterbitkan peraturan mengenai Prosedur Penerbitan Ijin Prinsip Perubahan Penananaman Modal Asing yang jelas dan dapat dipahami para investor untuk menjamin kepastian hukum dalam Investasi terutama dalam Ijin Prinsip Perubahan Penananaman Modal Asing.

\section{F. Penutup}

\section{Kesimpulan}

a. Prosedur dalam menerbitkan Ijin Prinsip Perubahan Penanaman Modal Asing harus memenuhi ketentuan dalam Undang-Undang Nomor 25 Tahun 2007 Tentang Penanaman Modal Pasal 25 ayat 4, Peraturan Kepala Badan Koordinasi Penanaman Modal Republik Indonesia Nomor 12 Tahun 2013 tentang perubahan atasa Peraturan Kepala Badan Koordinasi Penanaman Modal Nomor 5 Tahun 2013 tentang Pedoman dan tata cara perizinan dan non perizinan Penanaman Modal khususnya : Pasal 103 ayat (2), Pasal 103 ayat (3), Pasal 103 ayat (5) : Pasal 103 ayat (5) b : Pasal 103 ayat (6), Pasal 103 ayat (6) a.

b. Kepastian hukum izin investasi sesuai dengan prinsip Penanaman Modal Asing dikaitkan dengan Putusan Pengadilan Tata Usaha Negara Jakarta Nomor : 43/G/2014/PTUN-JKT, tanggal 17 Juli 2014 tidak terpenuhi karena telah melanggar prosedur yang ditentukan oleh Undang-Undang Nomor 25 Tahun 2007 Tentang Penanaman Modal Pasal 25 ayat 4, Peraturan Pemerintah Nomor 38 Tahun 2007 tentang Pembagian Urusan Pemerintahan antara Pemerintah, Pemerintahan Daerah Provinsi dan Pemerintah Daerah Kabupaten/Kota, dan Peraturan Kepala Badan Koordinasi Penanaman Modal Republik Indonesia Nomor 12 Tahun 2013 tentang perubahan atas Peraturan Kepala Badan Koordinasi 
Penanaman Modal Nomor 5 Tahun 2013 tentang Pedoman dan tata cara perizinan dan non perizinan Penanaman Modal.

\section{Saran}

a. Badan Koordinasi Penanaman Modal sebagai Lembaga Pemerintah Non Departemen yang berada di bawah dan bertanggung jawab langsung kepada Presiden Khusus untuk urusan pemerintahan di bidang penanaman modal berwenang menolak/menyetujui dalam menerbitkan Ijin Prinsip Perubahan Penanaman Modal seharusnya memenuhi Prosedur Penerbitan Ijin Prinsip Perubahan Penananaman Modal Asing yang diterbitkan berdasarkan Undang-Undang Nomor 25 Tahun 2007 Tentang Penanaman Modal dan peraturan lain yang berlaku untuk menjamin adanya kepastian hukum.

b. Perlu diterbitkan peraturan mengenai Prosedur Penerbitan Ijin Prinsip Perubahan Penananaman Modal Asing yang jelas dan dapat dipahami para investor untuk menjamin kepastian hukum dalam Investasi terutama dalam Ijin Prinsip Perubahan Penananaman Modal Asing. 


\section{Daftar Pustaka}

Ali, H. Zainuddin Aspek Hukum Penanaman Modal di Indonesia, Yayasan Masyarakat Indonesia Baru, 2014.

Attamimi, A. Hamid A. Peranan Keputusan Presiden Republik Indonesia dalam Penyelenggaraan Pemerintahan Negara; Suatu Studi Analisis Mengenai Keputusan Presiden yang Berfungsi Pengaturan dalam Kurun Waktu Pelita IPelita IV. Disertasi Ilmu Hukum Fakultas Pascasarjana Universitas Indonesia. Jakarta. 1990.

HS, Salim dan Budi Sutrisno, Hukum Investasi di Indonesia, Jakarta, Sinar Grafika, 2010.

Ilmar, Aminuddin, Hukum Penanaman Modal di Indonesia, Jakarta, Kencana, Jakarta, 2004

Marzuki, Peter Mahmud. Penelitian Hukum, Kencana Prenada Media Group, Jakarta, 2005

Rokhmatussa'diyah, Ana dan Suratman, Hukum Investasi dan Pasar Modal, Jakarta, Sinar Grafika, 2010.

Undang-Undang Nomor 25 Tahun 2007 Tentang Penanaman Modal

Undang-Undang Republik Indonesia Nomor 39 Tahun 2008 Tentang Kementrian Negara.

http://id.wikipedia.org/wiki/Badan_Koordinasi_Penanaman_Modal diakses tanggal 23 Januari 2015. 